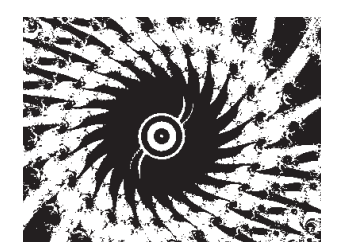

doi:10.5559/di.21.4.06

\title{
PREGLED ISTRAŽIVANJA INFRAHUMANIZACIJE
}

Ajana LÖW

Filozofski fakultet, Zagreb

UDK: 316.613.4:316.454.3

Pregledni rad

Primljeno: 12. 5. 2012.

Fenomen infrahumanizacije odnosi se na pojavu negiranja ljudskih karakteristika pripadnicima vanjske grupe, koja se očituje u manjoj sklonosti pripisivanju doživliaja sekundarnih emocija vanjskoj grupi u odnosu na vlastitu (Leyens i sur., 2000.). Takvo diferencijalno atribuiranje posliedica je pretpostavke o specifičnosti sekundarnih emocija za ljudska bića: dok primarne emocije smatramo karakterističnima i za liude i za životinje, sekundarne emocije za nas su jedinstveni procesi svojstveni samo ljudima. Istraživanja su višestruko potvrdila postojanje fenomena infrahumanizacije na eksplicitnim i implicitnim mjerama, uz upotrebu podražajnoga materijala. Najboljim prediktorom pojave ovoga fenomena pokazao se stupanj identifikacije s vlastitom grupom, dok faktori grupnoga statusa i postojanja sukoba među grupama imaju manje značenje nego što se pretpostavljalo. Na reduciranje infrahumanizacije teško je utjecati, jer je posljedica automatskih misaonih procesa, a okolina sudjeluje u njegovu pojačavanju i održavanju. U radu je dan pregled dosadašnjih spoznaja o infrahumanizaciii te opis najčešćih metoda koje se rabe u provjeri toga fenomena. Navedeni su uvjeti koji dovode do infrahumanizacije, u pogledu karakteristika vlastite grupe i vanjske grupe. Opisane su i kritike i prigovori konceptualizaciji. Na kraju rada istaknute su neke društvene implikacije ovoga fenomena te su navedene smjernice za provedbu budućih istraživanja.

Ključne riječi: infrahumanizacija, negiranje ljudskosti, međugrupni odnosi, atribucije doživljavanja emocija

$\triangle$ Ajana Löw, Filozofski fakultet Sveučilišta u Zagrebu, Odsjek za psihologiju, Katedra za socijalnu psihologiju, Ivana Lučića 3, 10000 Zagreb, Hrvatska.

E-mail: alow@ffzg.hr 
Ideja o konceptu infrahumanizacije potaknuta je proučavanjem ljudskoga ponašanja u sukobima, posebice $u$ genocidu, kao krajnjem obliku međugrupnoga nasilja. Istraživači su se pitali kako su ljudska bića spremna počiniti takva zlodjela. Pretpostavljali su da odgovor leži u određenom psihološkom procesu kojim ljudi opravdavaju prelaženje uobičajenih moralnih granica. U osnovi takva procesa mora se nalaziti moralno isključivanje protivnika - ako je ponašanje prema protivniku izvan granica unutar kojih postoje moralne vrijednosti i uobičajena pravila jednakosti, bilo kakav oblik nasilja prema njemu bit će dopušten i opravdan (Opotow i sur., 2005.). Da bi se protivnika postavilo izvan moralnih granica, on ne smije biti čovjek niti imati ljudska obilježja; mora se doživljavati nižim bićem na evolucijskoj ljestvici. Iako je sam koncept infrahumanizacije relativno nov u psihološkoj literaturi, psihološki fenomen negiranja ljudskosti pojedincima i grupama odavno je prepoznat te je privlačio zanimanje mnogih autora, a najčešće se označavao terminom dehumanizacija.

\section{POVIJESNI RAZVOJ IDEJE O DEHUMANIZACIJI}

Jedan od prvih autora koji se bavio socijalno-psihološkom pojavom negiranja ljudskosti bio je Bar-Tal (1989.; 2000.), koji je pretpostavio da je dehumanizacija specifična strategija delegitimizacije vanjske ${ }^{1}$ grupe. Definira je kao postupak svrstavanja vanjske grupe u kategoriju neljudskih bića, koristeći se ili kategorijama suphumanih bića, poput životinja, ili kategorijama negativno evaluiranih nadljudskih bića, poput demona, čudovišta ili sotona. Temelji se na sličnim principima kao i predrasude, no ima neka jedinstvena obilježja koja je razlikuju od toga koncepta: vanjska grupa trajno je postavljena izvan granica uobičajenih normi i vrijednosti koje vladaju u zajednici, pa se prema njoj redovito javljaju intenzivne negativne emocije, poput gađenja ili mržnje, kao i agresivna ponašanja. Prema navodima Bar-Tala, dehumanizacija je važna funkcija za pojedince i grupe: opravdava negativna ponašanja počinjena vanjskoj grupi, nudeći kognitivno objašnjenje za njihovo činjenje.

Na sličan je način o dehumanizaciji govorio Staub (1989.), koji se u svojim radovima o genocidu osobito usmjerio na njezine razorne društvene posljedice. Ističe kako su autohtone grupe u zajednici osobito često dehumanizirane, što ih čini lakom metom nasilja. Nadalje, naglašava kako dehumanizacija ima jednu od ključnih uloga u održavanju nerješivoga sukoba (engl. intractable conflict), jer članovima grupe nudi objašnjenje i opravdanje zašto je sukob izbio, zašto se održava i zašto je nasilan. 
DRUŠ. ISTRAŽ. ZAGREB GOD. 21 (2012),

BR. 4 (118)

STR. $923-948$

LÖW, A.: PREGLED...
Rane ideje o dehumanizaciji iznio je i Bandura (1999.; 2002.), koji dehumanizaciju smatra dijelom procesa moralnoga distanciranja (engl. moral disengagement). Po njegovu mišljenju, agresivna ponašanja prema vanjskoj grupi određena su postupnim isključivanjem moralne organizacije koja regulira stavove i ponašanja pojedinca ili grupe. Isključivanje moralne organizacije obuhvaća nekoliko stadija: a) kognitivnu rekonstrukciju neprihvatljivog ponašanja (npr. moralno opravdavanje), b) podcjenjivanje aktivne uloge pojedinca u neprihvatljivom ponašanju (npr. pomicanje odgovornosti), c) reinterpretaciju posljedica takva ponašanja, d) derogaciju žrtava (dehumanizacija). Prema tome, dehumanizacija je strategija moralnoga distanciranja koja djeluje u završnom stadiju ovoga procesa, usmjeravajući se izravno na žrtve. Lišavanjem pripadnika vanjske grupe ljudskih karakteristika isključuje se samocenzura, što obustavlja emocionalne reakcije empatije prema njima i čini jednostavnijim činjenje nemoralnih djela. Opisani model potvrđen je u istraživanju Bandure i sur. (1975.), u kojem je utvrđen utjecaj dehumanizacije žrtve i smanjenog osjećaja osobne odgovornosti za povećanje intenziteta primijenjene kazne.

Schwartz i Struch (1989.) u svojem su pristupu dehumanizaciji stavili naglasak na ulogu hijerarhije vrijednosti vlastite grupe, kroz koju se odražava gledište grupe o tome što čini temeljnu ljudsku prirodu. Ako neka vanjska grupa nema jednaku hijerarhiju vrijednosti kao i naša grupa, to može stvoriti dojam da članovima vanjske grupe nedostaju obilježja ljudskosti. Najčešće vrijednosti koje se smatraju jedinstveno ljudskima jesu "prosocijalne" vrijednosti (npr. jednakost, solidarnost), jer uključuju moralnost i sliku čovjeka kao društvenoga bića, dok "hedonističke" vrijednosti (npr. užitak, uzbudljiv život) izražavaju individualne ciljeve koje dijele neljudske vrste. Ove pretpostavke potvrđene su $u$ istraživanju Schwartza i Strucha (1989.), u kojem je utvrđena korelacija između percepcije ljudskosti vanjske grupe i percepcije sličnosti vrijednosti između grupa kod Židova i Arapa u Izraelu.

Opotow (1990.) smatra da je dehumanizacija simptom moralnog isključivanja (engl. moral exclusion), točnije, psihološki proces koji se javlja kada percipiramo da se neka druga grupa nalazi izvan granica u kojima se primjenjuju uobičajene moralne vrijednosti i pravila. Takva percepcija vodi do ideje da su "moralno isključeni" pojedinci zanemarivi i beskorisni za zajednicu, stoga činjenje neprihvatljivih ponašanja prema njima postaje jednostavnije ili, čak, pošteno i ispravno. Opotow naglašava važnost prepoznavanja dehumanizacije kao simptoma, kako bi se spriječio proces moralnog isključivanja. 
Oslanjajući se na opisana tumačenja, Jacques Philippe Leyens uveo je nešto drugačiju konceptualizaciju negiranja ljudskosti, koju je nazvao infrahumanizacija.

\section{FENOMEN INFRAHUMANIZACIJE}

Fenomen infrahumanizacije odnosi se na pojavu da pripadnicima vanjske grupe nismo skloni pripisati karakteristike jedinstvene za ljude te ih na taj način simbolički spuštamo na razinu životinja (Leyens i sur., 2000.). Fenomen se manifestira prije svega $u$ različitom pripisivanju doživljavanja emocija vanjskoj grupi u odnosu na vlastitu. Za primarne emocije vjerujemo da ih u jednakoj mjeri mogu doživjeti i pripadnici vlastite grupe i pripadnici vanjske grupe, dok za sekundarne emocije nismo skloni vjerovati da ih u jednakom stupnju mogu doživjeti i pripadnici vanjske grupe. Objašnjenje takva diferencijalnog atribuiranja leži u pretpostavci o doživljaju specifičnosti sekundarnih emocija za ljudska bića: primarne emocije smatramo karakterističnima i za ljude i za životinje, a sekundarne su emocije jedinstveni procesi svojstveni samo ljudima.

Postojanje fenomena infrahumanizacije empirijski je potvrđeno u nizu istraživanja. Pokazalo se da sudionici primarne emocije jednako povezuju s vlastitom grupom i s vanjskom grupom, dok sustavno asociraju više sekundarnih emocija (emocija koje percipiraju jedinstveno ljudskima) uz vlastitu grupu nego uz vanjske grupe. Takav je nalaz postojan u raznim međugrupnim kontekstima (npr. Paladino i sur., 2002.; Vaes i sur., 2003.; Castano i Giner-Sorolla, 2006.).

Da bi se objasnio fenomen infrahumanizacije, razvijen je Model infrahumanizacije (Leyens i sur., 2007.), koji se temelji na tri hipoteze (Slika 1). Prva hipoteza pretpostavlja da se doživljavanje sekundarnih emocija percipira jedinstveno ljudskom karakteristikom i prikazana je odnosima B-C i B'-C'. Druga hipoteza vezana je uz poricanje jedinstveno ljudskih karakteristika pripadnicima vanjske grupe, odnosno njihovo asociranje uz pripadnike vlastite grupe, što je prikazano odnosima A-C i A'-C'. Zadnja hipoteza slijedi dedukcijom iz prve dvije hipoteze: vanjskoj grupi poriče se doživljavanje sekundarnih emocija, a vlastitoj se grupi to obilježje odobrava, što je prikazano odnosima A-B i A'-B'.

Iako suptilan, fenomen infrahumanizacije ima značajne posljedice na ljudsko ponašanje u svakodnevnom životu. Uzrok tome jesu tri njegova ključna obilježja, o kojima će biti detaljnije riječi u ovom radu: sveobuhvatnost, nesvjesni karakter i podložnost socijalnim utjecajima. Fenomen možemo smatrati sveobuhvatnim, jer se javlja i bez postojanja sukoba među grupama te neovisno o statusu grupa (Demoulin i sur., 
DRUŠ. ISTRAŽ. ZAGREB GOD. 21 (2012),

BR. 4 (118),

STR. $923-948$

LÖW, A.: PREGLED...

O SLIKA 1

Temeline hipoteze u osnovi Modela

infrahumanizacije

(Leyens i sur., 2007.)
2005.), zbog automatskih procesa u podlozi fenomena teško je utjecati na njega i ljudi nisu svjesni njegova postojanja, a okolina sudjeluje u pojačavanju i održavanju fenomena (Leyens i sur., 2007.).

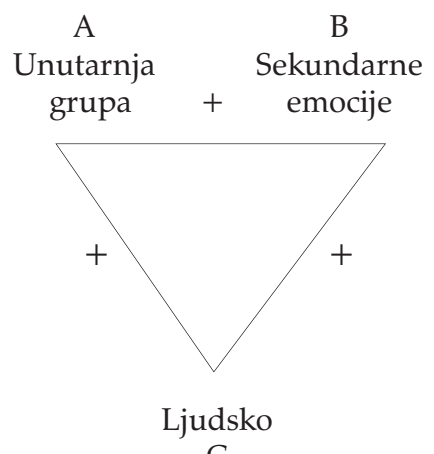

C

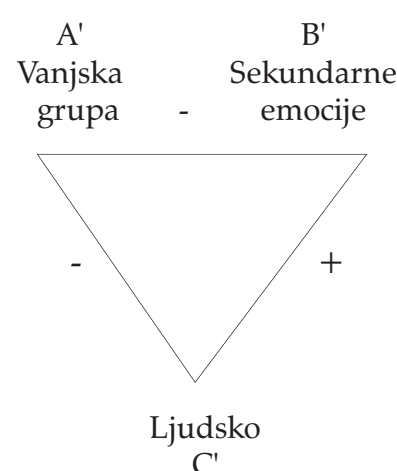

$\mathrm{C}^{\prime}$

\section{TEORIJSKA PODLOGA KONCEPTA INFRAHUMANIZACIJE}

Teorijsko polazište koncepta infrahumanizacije čine dva konstrukta: esencijalizam i unutargrupna pristranost (Leyens i sur., 2007.).

Esencijalizam (Medin, 1989.; Rothbart i Taylor, 1992.; sve prema Leyens i sur., 2007.) u psihologiji je, u odnosu na ostale društvene znanosti, relativno nov pojam, a odnosi se na vjerovanje da postoje bitne biološke razlike između pojedinih socijalnih kategorija koje izravno dovode do ponašajnih, kognitivnih i emocionalnih razlika među njima. Esencijalisti tvrde da bitne razlike među grupama ne moraju biti isključivo biološkoga podrijetla, nego se mogu temeljiti i na jeziku (npr. Francuzi imaju poseban jezik) ili religiji (npr. Židovi su ljudi odabrani od Boga). Iz esencijalističkih vjerovanja proizlazi ideja da postoji kontinuum ljudskosti među živim bićima, koja je nužna za pojavu infrahumanizacije.

Vjerovanje da se pojedine socijalne grupe razlikuju u svojoj bíti u potpunoj je suprotnosti s idejom o grupama kao socijalnim konstrukcijama. Prema pristupu socijalnoga konstruktivizma, države su nastale kao posljedica slučajnih događaja u povijesti i mogu se promijeniti, a rase su izmišljene kako bi se opravdala socijalna dominacija. Socijalni konstruktivisti stoga postavljaju pitanje esencijalistima kako nešto toliko arbitrarno kao što je socijalna grupa može imati bít. Međutim, najveća poteškoća u esencijalističkom shvaćanju svijeta jest u tome što je ljudima vrlo intuitivno i razumljivo, zbog čega ga lako prihvaćaju, nesvjesni da rade kognitivnu pogrešku. Iz opažanja da su ljudi vrlo skloni esencijalističkom načinu razmišljanja proizašla su prva Leyensova istraživanja. 
DRUŠ. ISTRAŽ. ZAGREB GOD. 21 (2012) BR. 4 (118)

STR. $923-948$

LÖW, A.: PREGLED...
Drugi konstrukt na kojem je Leyens temeljio svoja razmišljanja jest unutargrupna pristranost, koju možemo definirati kao sklonost favoriziranja vlastite grupe i derogacije vanjskih grupa (Tajfel, 1981.). Unutargrupna pristranost proizlazi iz motivacije za pozitivnim socijalnim identitetom, zbog koje se ponašamo i mislimo tako da postignemo i održavamo pozitivnu razliku između vlastite grupe i relevantnih vanjskih grupa. Infrahumanizacija odražava unutargrupnu pristranost, jer u sebi sadrži favoriziranje vlastite grupe - ljudska je bít viđena kao povlastica vlastite grupe - kao i derogaciju vanjske grupe - ljudska se bít negira vanjskoj grupi.

Ipak, valja naglasiti da infrahumanizaciju ne možemo jednostavno svesti na unutargrupnu pristranost. Naime, istraživanja sustavno pokazuju da je fenomen infrahumanizacije prisutan i u pripisivanju pozitivnih i u pripisivanju negativnih emocija (Leyens i sur., 2007.). Drugim riječima, svojoj ćemo grupi biti skloniji pripisati snažnije doživljavanje pozitivnih, ali i snažnije doživljavanje negativnih emocija, što nije u skladu s pretpostavkom o unutargrupnoj pristranosti, prema kojoj vlastitu grupu vežemo isključivo uz pozitivne karakteristike, a snažno negiramo postojanje negativnih karakteristika. Čini se da je motivacija da se vlastita grupa prikaže ljudskijom od vanjske grupe snažnija od motivacije da se vlastita grupa prikaže pozitivnijom od nje, jer prva diferencijacija više pridonosi razlikovanju biti socijalnih kategorija i dovodi do lakšega moralnog isključivanja.

\section{Razlike između infrahumanizacije i dehumanizacije}

Infrahumanizacija se od dehumanizacije razlikuje prije svega $\mathrm{u}$ intenzitetu ili snazi negiranja ljudskosti. Dehumanizacija pretpostavlja potpuno obescjenjivanje vanjske grupe, njezina digniteta te njezine sposobnosti i prava za doživljavanje emocija (Opotow, 1990.). Za razliku od toga, infrahumanizacija ne uključuje potpuno moralno isključivanje vanjske grupe, nego samo umanjivanje njezine važnosti u odnosu na vlastitu grupu. Štoviše, kod dehumanizacije nije važna usporedba između vlastite grupe i vanjske grupe, nego je žarište isključivo na vanjskoj grupi i njezinu obescjenjivanju. Zato se dehumanizacija javlja samo u krajnjim okolnostima, kada su međugrupni odnosi vrlo kritični, poput oružanih sukoba. Idejom infrahumanizacije Leyens je htio pokazati da se fenomen sličan dehumanizaciji, ali mnogo slabije snage i vrlo suptilan, može javiti i u svakodnevnom životu.

Osim u kvantitativnom smislu, infrahumanizacija se razlikuje od dehumanizacije i u kvalitativnom smislu. Tu razliku istaknuo je Haslam (2006.), govoreći kako se vanjskim grupama može negirati ono što je tipično ljudsko (što se često može 
DRUŠ. ISTRAŽ. ZAGREB GOD. 21 (2012),

BR. 4 (118),

STR. 923-948

LÖW, A.: PREGLED... susresti kod ljudi, ali ne isključivo kod ljudi) i ono što je jedinstveno ljudsko. Ovisno o tome, razlikuje dvije vrste dehumanizacije: mehanističku i animalističku. Mehanistička dehumanizacija odnosi se na negiranje tipično ljudskih karakteristika, što rezultira time da pripadnike vanjske grupe doživljavamo poput strojeva. To rezultira predodžbom da su hladni, nefleksibilni i pasivni. Animalistička dehumanizacija odnosi se na negiranje jedinstveno ljudskih karakteristika, što rezultira time da pripadnike vanjske grupe doživljavamo poput životinja. Takav misaoni proces rezultira predodžbom da su ti ljudi nekulturni, nemoralni i primitivni. Potonja vrsta dehumanizacije zapravo odgovara konceptu infrahumanizacije.

Iako su koncepti infrahumanizacije i dehumanizacije bliski i u mnogim se obilježjima preklapaju, istraživanja su pokazala da je dehumanizacija prisutna i unutar vlastite grupe - procjenjujemo da ostali pripadnici naše grupe imaju manje ljudskih karakteristika od nas samih, što je čini međugrupnim i interpersonalnim fenomenom (Haslam i sur., 2007.). Za razliku od nje, infrahumanizacija postoji isključivo na međugrupnoj razini (Cortes i sur., 2005.).

\section{RANA ISTRAŽIVANJA: STVARANJE KONCEPTA}

\section{Odabir emocija kao dimenzije na kojoj se ostvaruje infrahumanizacija}

Prva istraživanja infrahumanizacije nastojala su provjeriti koje osobine ljudi smatraju jedinstvenima našoj vrsti, odnosno za što sve mislimo da pripada ljudskoj biti. Kako bi to utvrdili, Leyens i sur. pitali su svoje sudionike da procijene koje karakteristike ljudi imaju, a životinje nemaju (2000.). Najčešći odgovori mogli su se svrstati u tri kategorije: inteligencija i mišljenje, jezik i komunikacija te sentimenti (engl. sentiments). Nitko od ispitanika nije odabrao odgovor - emocije (engl. emotions). Od svih pojmova koje su ispitanici odabrali, Leyens se odlučio zadržati na pojmovima sentimenti i emocije, pod pretpostavkom da su sentimenti nešto što pripisujemo samo ljudima (tzv. "socijalni" osjećaji), ${ }^{2}$ dok emocije nisu. Ako je ta pretpostavka točna, to bi značilo da su ta dva pojma prikladna za ispitivanje infrahumanizacije. Svoju odluku Leyens je potkrijepio trima ključnim razlozima (Leyens i sur., 2007.). Prvi razlog proizlazi iz samih rezultata njegova istraživanja: za razliku od inteligencije i jezika, kod emocija postoji jasno razlikovanje karakteristika koje su samo ljudske i onih koje posjeduju i životinje. Drugo, inteligencija i jezik višestruko su istraživani u kontekstu njihove povezanosti s diskriminacijom, dok je mnogo manje istraživana povezanost emocija i diskriminacije. Treće, za razliku od inteligencije i jezika, emocije nisu povezane s normama jednakosti i pravednosti, koje 
mogu potaknuti socijalno poželjno odgovaranje. Uza sve navedeno, razlikovanje sentimenata i emocija omogućit će mu jednostavno kreiranje nacrta s eksperimentalnom i kontrolnom grupom.

\section{Provjera hipoteze B-C i B'-C': \\ Primarne emocije nasuprot sekundarnim emocijama}

Idući koraci nalagali su da se istraživači podrobnije posvete leksičkoj razlici između "sentimenata" i "emocija". Ključnu studiju proveli su Demoulin i sur. (2004.a), koji su utvrdili da se ispitanici iz različitih kultura slažu u procjenama da su osjećaji jedinstveni ljudima (sentimenti) manje intenzivni, manje uočljivi i duljega trajanja. Uz to, procijenjeni su kao više internalno uzrokovani i kao oni koji se pojavljuju kasnije u životu. S druge strane, osjećaji koji nisu jedinstveni za ljude (emocije) procijenjeni su intenzivnijima, lakše uočljivima u interakciji, kraćega trajanja i urođenima. Istraživači su uočili značajno poklapanje tih opisa s karakteristikama sekundarnih, odnosno primarnih, emocija, ${ }^{3}$ kako ih je, na temelju svojih istraživanja, opisao Ekman (1992.). Odlučili su doživljavanje sekundarnih emocija proglasiti obilježjem koje prosječan ispitanik procjenjuje jedinstvenima za ljude, a primarne emocije obilježjem koje smatra zajedničkim i ljudima i životinjama. Time je nastala osnova za prvu hipotezu modela infrahumanizacije, koja je i preduvjet za dvije glavne hipoteze koje su kasnije ispitane. No prije daljnjega pregleda empirijskih nalaza, radi bolje preglednosti sadržaja, ukratko će biti opisane najčešće metode provjere modela infrahumanizacije.

\section{NAJČEŠĆE METODE PROVJERE MODELA INFRAHUMANIZACIJE}

Najčešća implicitna mjera jest Test implicitnih asocijacija (IAT), koji je namijenjen ispitivanju implicitnih stavova. ${ }^{4}$ Specifično, $\mathrm{u}$ istraživanjima ovoga fenomena, IAT se rabi tako da se uparuju primarne i sekundarne emocije s tipičnim imenima pripadnika vlastite grupe i vanjske grupe, pri čemu se pretpostavlja da će sukladni podražaji (podražaji koji su snažnije asocirani) biti sekundarne emocije i vlastita grupa, odnosno primarne emocije i vanjska grupa. U situaciji A (situaciji sukladnih podražaja) jedna se tipka rabi za sekundarne emocije i tipična imena pripadnika vlastite grupe, a druga za primarne emocije i tipična imena pripadnika vanjske grupe. $U$ situaciji B (situaciji nesukladnih podražaja) jedna se tipka rabi za primarne emocije i vlastitu grupu, a druga za sekundarne emocije i vanjsku grupu. Računa se razlika između vremena reakcije $u$ situaciji A $i$ vremena reakcije u situaciji B. Prema pretpostavci modela infrahumanizacije o snažnijem (bržem) asociranju sekundarnih emocija i vlastite grupe (nego sekundarnih emocija i vanjske grupe), trebalo bi se javiti dulje vri- 
DRUŠ. ISTRAŽ. ZAGREB GOD. 21 (2012),

BR. 4 (118),

STR. 923-948

LÖW, A.: PREGLED... jeme reakcije kada se ispitanik nalazi u situaciji nesukladnih podražaja (primarne emocije - vlastita grupa i sekundarne emocije - vanjska grupa) nego kada se nalazi u situaciji sukladnih podražaja (sekundarne emocije - vlastita grupa i primarne emocije - vanjska grupa). Međutim, nedostatak ove tehnike $\mathrm{u}$ provjeri modela infrahumanizacije jest $\mathrm{u}$ tome što ne daje odgovor na pitanje javlja li se razlika u vremenu reakcije zbog toga što postoji brže povezivanje vlastite grupe i sekundarnih emocija ili vanjske grupe i primarnih emocija (Leyens i sur., 2007.).

Navedeni nedostatak uspješno rješava druga česta tehni$\mathrm{ka}$ - priređivanje (engl. priming). Ispitanike se subliminalno priređuje riječima koje asociraju na vlastitu ili vanjsku grupu, nakon čega se pridjeljuju riječi s popisa (emocije) u kategorije prema stupnju smislenosti. Fenomen infrahumanizacije očituje se $u$ duljem vremenu reakcije za točno kategoriziranje sekundarnih emocija u situaciji kada je osoba priređena riječju vezanom uz vanjsku grupu, nego kada je priređena riječju vezanom uz vlastitu grupu. Ovom metodom možemo jasno utvrditi je li dobivena razlika u vremenu reakcije posljedica različite brzine reagiranja isključivo na sekundarne emocije ovisno o uparivanju s vlastitom ili vanjskom grupom (Leyens i sur., 2007.).

Najčešća eksplicitna mjera jest odabir tipičnih atributa za vlastitu grupu i za vanjsku grupu. Ispitanike se najprije pita s kojom se grupom poistovjećuju, kako bi se međugrupni kontekst učinio istaknutim (engl. salient). Nakon toga čitaju popis od dvadesetak riječi (primarnih i sekundarnih emocija), polovica pozitivne, a polovica negativne valencije. Zadatak je ispitanika odabrati nekoliko karakteristika koje su tipične za vlastitu, odnosno vanjsku, grupu. Pojava fenomena infrahumanizacije očituje se $\mathrm{u}$ većem broju odabranih sekundarnih emocija za vlastitu grupu nego za vanjsku grupu. Rabe se i Skale procjene Likertova tipa za vlastitu grupu i za vanjsku grupu, na kojima se procjenjuje stupanj tipičnosti pojedinih atributa, čestina i intenzitet doživljavanja pojedinih emocija, kao i predviđanje intenziteta i trajanja emocija kao reakcije na situaciju.

$\mathrm{U}$ početku je $\mathrm{u}$ istraživanjima uzet velik broj primarnih $\mathrm{i}$ sekundarnih emocija, no s vremenom se, na temelju predistraživanja, početni popis pročistio. Izabrane su emocije za koje ljudi mogu najjasnije razlikovati jesu li ili nisu jedinstveno ljudske. Popis emocija koji se danas najčešće rabi jest onaj Demoulina i sur. (2004.a), koji uključuje 16 emocija: 4 primarne pozitivne emocije (radost, zadovoljstvo, uzbuđenje, užitak), 4 sekundarne pozitivne emocije (nada, oduševljenje, optimizam, ponos), 4 primarne negativne emocije (ljutnja, uplašenost, bol, strah) i 4 sekundarne negativne emocije (gnjev, krivnja, pesimizam, sram). 


\section{PROVJERA MODELA INFRAHUMANIZACIJE}

Da bi se utvrdila valjanost i širina primjene dviju glavnih hipoteza modela infrahumanizacije, provedeno je njegovo testiranje upotrebom nekoliko istraživačkih paradigmi (Demoulin i sur., 2004.b; Leyens i sur., 2003.).

\section{Provjera hipoteze A-B i A'-B': Veća sklonost pripisivanja sekundarnih emocija vlastitoj grupi nego vanjskoj grupi}

Prvi korak u testiranju modela bio je potvrditi da postoji veća sklonost pripisivanja sekundarnih emocija vlastitoj grupi nego vanjskoj grupi. Paladino i sur. (2002.) u svojem su istraživanju ispitali nekoliko grupa različita statusa koristeći se IAT-om. Utvrdili su kraće vrijeme reakcije na podražaje kada je vlastita grupa bila uparena sa sekundarnim, a vanjska grupa s primarnim emocijama, nego obrnuto. Slični su rezultati dobiveni kada su primarne i sekundarne emocije zamijenjene riječima ${ }^{5}$ vezanima uz životinje i ljude (Viki i sur., 2006.). Međutim, klasična verzija IAT-a ne daje odgovor na pitanje javlja li se efekt zbog toga što postoji brže povezivanje vlastite grupe i sekundarnih emocija ili vanjske grupe i primarnih emocija. Kako bi to provjerili, Boccato i sur. (2007.) proveli su eksperiment u kojem su na belgijskim studentima upotrijebili metodu priređivanja. Rezultati su pokazali da ispitanici brže kategoriziraju sekundarne emocije kada su priređeni riječju "Belgijanac" nego kada su priređeni riječju "Arapin", dok se vrijeme kategoriziranja za primarne emocije ne razlikuje. Dakle, efekt je posljedica različite brzine reagiranja na sekundarne emocije, ali ne i na primarne.

Osim različita reagiranja na situacije kada su sekundarne emocije uparene s vlastitom grupom u odnosu na njihovo $\mathrm{u}-$ parivanje s vanjskom grupom, pokušalo se utvrditi hoće li postojati i tendencija češćeg odabira sekundarnih emocija kao obilježja svoje grupe nego kao obilježja vanjske grupe, kada se takav izbor ponudi (primjenom eksplicitnih mjera). I u ovom slučaju potvrđena je pretpostavljena hipoteza (Leyens i sur., 2001.). Takvi su nalazi ponovljeni u mnogim istraživanjima s pripadnicima različitih grupa.

Nadalje, utvrđena je i važnost vremenske dimenzije emocija - pojedinci su skloni donositi procjene različite duljine trajanja emocionalnoga doživljaja za vlastitu grupu i za vanjsku grupu. U istraživanju Gaunt i sur. (2005.), belgijski studenti trebali su, prije utakmice između Belgije i Turske, predviđati trajanje emocija pripadnika vlastite grupe i vanjske grupe kao reakciju na pobjedu ili poraz. Procijenili su da će tri dana nakon utakmice intenzitet sekundarnih emocija pasti, ali puno više za turske nego za belgijske navijače. Za primarne emocije nije dobivena razlika. Dakle, iako ljudi mogu vjero- 
DRUŠ. ISTRAŽ. ZAGREB GOD. 21 (2012),

BR. 4 (118),

STR. 923-948

LÖW, A.: PREGLED... vati da je vanjska grupa sposobna reagirati na događaj jednako intenzivno kao i njihova, misle da je njezin način dugoročnoga suočavanja s tim događajem mnogo manje ljudski nego onaj vlastite grupe.

Druga linija istraživanja vezana uz provjere ove hipoteze bavila se konceptom rehumanizacije. Ako pojedinci prisvajaju ljudske karakteristike svojoj grupi, trebali bi pružati otpor pokušajima vanjske grupe da te karakteristike "preotme". Drugim riječima, morali bi negativno reagirati ako pripadnici vanjske grupe izraze sekundarne emocije, jer to doživljavaju kao prijetnju oduzimanjem nečega što pripada samo njima. Ova pretpostavka provjeravana je u više navrata. U istraživanju Gaunt i sur. (2002.) ispitanici su se bolje prisjećali rečenica koje sa sekundarnim emocijama povezuju vanjsku grupu nego vlastitu. Informacija da bi vanjska grupa mogla doživjeti sekundarnu emociju za njih je bila neuobičajena i nesukladna s postojećim uvjerenjima, pa je zato bila posebno dobro zapamćena.

Vaes i sur. (2003.) zapitali su se hoće li ljudi reagirati prosocijalnim ponašanjem ako pripadnici vanjske grupe sami izraze da osjećaju neku sekundarnu emociju, u kombinaciji s molbom za pomoć. Kako bi na to odgovorili, upotrijebili su metodu izgubljene e-pošte, prilagodbu Milgramove tehnike izgubljena pisma. Poslali su e-poštu na velik broj očito pogrešnih adresa, s molbom za pružanje hitne pomoći u obliku davanja informacija. Imaginarna osoba obraćala se primatelju koristeći se primarnim ili sekundarnim emocijama, a predstavila se ili kao pripadnik grupe primatelja (osoba koja radi na sveučilištu) ili kao pripadnik vanjske grupe (osoba koja radi za privatnu organizaciju). Postotak odgovora nije se razlikovao s obzirom na eksperimentalnu situaciju, ali su dobivene razlike $\mathrm{u}$ tonu kojim je ispitanik odgovarao - prema stupnju ugodnosti i pristojnosti te spremnosti na pružanje stvarne pomoći. Očekivano, razlika se nije pojavila u situacijama kada je pošiljatelj izražavao primarne emocije, ali se pojavila kada je izražavao sekundarne emocije.

Cuddy i sur. (2007.) provjerili su hoće li diferencijalno pripisivanje emocija vlastitoj i vanjskoj grupi biti prisutno i uz dobivanje dodatnih informacija koje opisuju iznimno tešku životnu situaciju u kojoj se nalazi pripadnik vanjske grupe. Zavisna varijabla bila je usporedba procjene intenziteta i čestine doživljavanja sekundarnih emocija kod pripadnika vanjske grupe i pripadnika vlastite grupe nakon dobivanja informacije o tome da je ciljna osoba bila žrtva uragana Katrina, $u$ kojoj joj je nestalo maloljetno dijete. Pokazalo se da su ispitanici vjerovali da žrtva pripadnica vanjske grupe doživljava manje sekundarnih emocija (npr. tugovanje, žaljenje, bol) nego žrtva pripadnica njihove vlastite grupe. Dakle, čak i uz 
DRUŠ. ISTRAŽ. ZAGREB GOD. 21 (2012)

BR. 4 (1 18)

STR. 923-948

LÖW, A.: PREGLED... dobivanje informacija da je žrtvi vrlo teško, infrahumanizacija se održala zbog snažnoga djelovanja motivacijskih procesa. Čini se da ljudi ne reagiraju pozitivno kada pripadnik vanjske grupe pokaže sekundarne emocije i da je želja za infrahumanizacijom snažnija od osjećaja empatije.

\section{Provjera hipoteze A-C i A-C': Sklonost pripisivanju}

ljudskih karakteristika vlastitoj grupi, a životinjskih karakteristika vanjskoj grupi

Kako bi ispitali hipotezu o sklonosti pripisivanju ljudskih karakteristika vlastitoj grupi, a životinjskih vanjskoj, Vaes i sur. (2006.) proveli su dvije studije u Belgiji i Italiji. Sudionici su bili priređeni riječima vezanima uz vlastitu grupu ili uz vanjsku grupu i primarne ili sekundarne emocije. Priređivanje se sastojalo od premetanja riječi u rečenici (npr. "Posebno osjećajni Belgijanci su..."). Nakon toga morali su dovršiti niz nepotpunih riječi, koje su mogle biti dovršene $s$ referiranjem na ljudska obilježja (npr. c__ture; culture ili capture) ili bez njih. U objema studijama ispitanici koji su dobili rečenice s vlastitom grupom i sekundarnim emocijama producirali su najviše riječi koje su vezane uz ljudske karakteristike.

Drugu paradigmu kojom se htjela ispitati ista hipoteza osmislili su Boccato i sur. (2008.). Studenti iz sjeverne Italije subliminalno su priređeni slikama čovjeka ili majmuna, a zatim su trebali kategorizirati riječi na smislene i besmislene. Kritične riječi bila su imena iz sjevernoga ili južnoga dijela Italije. Ispitanici su davali brže odgovore za imena iz vlastite (sjeverne) regije kada su prethodno bili priređeni ljudskim licem. Ovo istraživanje, kao i studija Vaesa i sur., upućuje na zaključak da ljudi preferiraju vezati sekundarne emocije uz svoju grupu, jer takva veza implicira veći stupanj ljudskosti grupe.

\section{UVJETI KOJI DOVODE DO INFRAHUMANIZACIJE}

\section{Karakteristike vanjske grupe}

U istraživanjima je utvrđeno da su vanjske grupe podložne infrahumanizaciji, a provjeravan je utjecaj nekoliko ključnih faktora: statusa vanjske grupe, međusobne (ne)zavisnosti grupa i postojanja trenutačnoga sukoba među grupama.

Pokazalo se da je pojava fenomena neovisna o statusu vanjske grupe. Grupe visokoga statusa infrahumaniziraju se jednako kao i grupe niskoga statusa. Takvi rezultati dobiveni su na Belgijancima i Francuzima, stanovnicima Kanarskih otoka i Nijemcima te Britancima i stanovnicima SAD-a (Demoulin i sur., 2005.; Leyens i sur., 2001.; Paladino i sur., 2002.). Vaes i Paladino (2008.) ispitivali su moderatorski efekt statusa vanjske 
DRUŠ. ISTRAŽ. ZAGREB GOD. 21 (2012),

BR. 4 (118),

STR. 923-948

LÖW, A.: PREGLED... grupe u pojavi i manifestiranju infrahumanizacije. Ispitanicima iz sjeverne Italije dali su dugačak popis atributa koji su činili sadržaj raznih stereotipa i tražili da ih procijene na četiri dimenzije: tipičnost za vlastitu grupu, odnosno vanjsku gru$\mathrm{pu}$, karakterističnost za ljude i valencija. Odabrano je devet grupa, prema Modelu sadržaja stereotipa (Fiske i sur., 2002.), koji raspoređuje grupe uz dvije ortogonalne dimenzije: toplinu i kompetentnost. Tri grupe bile su nisko na toplini i visoko na kompetenciji (stanovnici SAD-a, Japanci i Nijemci), tri visoko na toplini i nisko na kompetenciji (južni Talijani, Brazilci i Kubanci), a preostale tri nisko na obje dimenzije (Romi, Albanci i Marokanci). Procjena karakterističnosti pojedinoga stereotipa za ljude predviđala je njegovu tipičnost za vlastitu gru$\mathrm{pu}$, uz kontrolu valencije. Procjena karakterističnosti stereotipa za ljude predviđala je i razlike u tipičnosti te karakteristike za vlastitu i vanjsku grupu za sve grupe koje su sudjelovale u istraživanju, neovisno o njihovu statusu. Ipak, rezultat dobiven za grupe nisko na obje dimenzije pokazuje da status nije nevažna varijabla. Što su karakteristike procijenjene tipičnijima za tu grupu, percipiralo ih se manje karakterističnima za ljude.

Delgado i sur. (2007.; prema Andrighetto, 2009.) pokazali su da je vjerojatnost infrahumanizacije veća ako vanjska grupa nije bliska našoj grupi, odnosno ako su grupe u međusobno nezavisnom odnosu. Sudionike su tražili da pripišu primarne i sekundarne emocije jednoj od niza zemalja (npr. Njemačkoj), regija na svijetu (npr. Južnoj Americi) i kontinenata (npr. Europi). Zatim su trebali rangirati grupe u terminima sličnosti, prijateljstva, informacije i statusa. Očekivano, ni jedna od varijabli nije predviđala pripisivanje primarnih emocija, a status nije predviđao pripisivanje sekundarnih emocija. Za razliku od toga, što su države, regije i kontinenti bili percipirani sličnijima, poznatijima i u većoj mjeri prijateljskima, pripisivano im je više sekundarnih emocija. Međutim, ovaj nalaz treba promatrati s oprezom, jer se neke grupe mogu međusobno percipirati kao vrlo bliske, ali istodobno neprijateljske. To se često događa zbog suprotnih interesa među grupama: kada se grupe nalaze $\mathrm{u}$ trenutačno aktivnom, gorućem sukobu ili pak tinjajućem sukobu koji karakteriziraju stalni napeti odnosi dviju strana (npr. stanovnici SAD-a i Meksikanci: Demoulin i sur., 2005.).

Osim u situacijama realnih sukoba, infrahumanizacija se može javiti i kada je sukob samo hipotetski. U istraživanju B. P. Cortesa (2005.; prema Delgado i sur., 2009.) simulirana je situacija međugrupne prijetnje. U usporedbi s kontrolnom situacijom bez dobivene relevantne informacije, Belgijanci koji govore francuskim jezikom infrahumanizirali su Poljake koji su im bili predstavljeni kao potencijalna konkurencija na 
DRUŠ. ISTRAŽ. ZAGREB GOD. 21 (2012) BR. 4 (118)

STR. 923-948

LÖW, A.: PREGLED... tržištu rada. Delgado i sur. (2009.) pronašli su i da prethodno priređivanje ispitanika prizorima nasilja pojačava efekt infrahumanizacije.

Iako sukob među grupama povećava vjerojatnost pojave fenomena, postojanje trenutačnoga konflikta nije nužan preduvjet za infrahumanizaciju. Fenomen se javlja i kod grupa među kojima nema trenutačnoga sukoba, primjerice, između Britanaca i Talijana (Viki i sur., 2006.), Britanaca i stanovnika SAD-a (Viki i Calitri, 2008.), Poljaka i stanovnika Kanarskih otoka (Delgado i sur., 2006.; prema Leyens i sur., 2007.), Francuza i Nijemaca (Rohmann i sur., 2005.).

\section{Karakteristike vlastite grupe}

Pri ispitivanju odrednica koje se vežu uz karakteristike vlastite grupe istraživači su se usmjerili na tri faktora: status vlastite grupe, grupnu kategorizaciju i identifikaciju s grupom.

U svojem istraživanju Leyens i sur. (2001.) primijetili su da, ovisno o statusu vlastite grupe, postoji razlika u rasponu karakteristika na kojima se pokazuje infrahumanizacija. Kod grupa visokoga statusa fenomen se javlja na više dimenzija, pa se uz emocije pripadnicima vanjske grupe osporava i posjedovanje određenih intelektualnih sposobnosti i karakteristika ličnosti koje su svojstvene ljudima. Za razliku od toga, kod grupa niskoga statusa fenomen je prisutan samo kada je riječ o emocijama. Čini se da dominantne grupe rabe više kriterija za infrahumanizaciju od submisivnih grupa. To se može objasniti činjenicom da imaju više resursa za suprotstavljanje vanjskoj grupi, pa su je spremnije otvoreno degradirati, na dimenzijama koje se mnogo otvorenije vezuju uz diskriminaciju nego emocije.

Istraživanja povezanosti infrahumanizacije s grupnom kategorizacijom provjeravala su javlja li se fenomen kod minimalnih grupa, odnosno onda kada članovi grupe nemaju nikakve zajedničke povijesti te se međusobno ne poznaju i raspodijeljeni su u grupe po slučaju. U tim studijama primijenjena je poznata Tajfelova paradigma minimalne grupe (Tajfel i sur., 1971.). Kofta i sur. (2008.) služili su se prilagođenom verzijom originalne paradigme minimalne grupe ( $\mathrm{u}$ kojoj su se sudionici dijelili prema preferenciji slikara Kleea ili Kandinskoga) na srednjoškolcima i studentima. U obje studije pojavio se i efekt infrahumanizacije i efekt unutargrupne pristranosti. Međutim, analizama je utvrđeno da su efekti nezavisni: nisu u međusobnoj korelaciji i samo intenzitet unutargupne pristranosti (a ne i intenzitet infrahumanizacije) moderira percepciju vanjske homogenosti.

Provjeru nalaza Kofte i sur. proveli su Demoulin i sur. (2009.), koristeći se složenijim nacrtom. Osmišljene su tri eksperimentalne situacije, s različitim stupnjem identifikacije sudionika s 
DRUŠ. ISTRAŽ. ZAGREB GOD. 21 (2012),

BR. 4 (118),

STR. 923-948

LÖW, A.: PREGLED... grupom. U situaciji A sudionici su po slučaju dodijeljeni u jednu od dvije grupe, u situaciji B mogli su birati u koju će grupu ići prema tome vole li više plavu ili crvenu boju, a u situaciji $C$ prema tome bi li voljeli više raditi s odraslima ili $\mathrm{s}$ djecom nakon završetka studija. Sudionici u situaciji B i C dobili su nakon odabira grupe zadatak da provedu 5 minuta $\mathrm{u}$ razmišljanju o tome po čemu je njihova grupa jedinstvena te da to zapišu na papir. Sudionici u situaciji A morali su razmišljati i pisati o svojem stavu prema onečǐscenju okoliša. Infrahumanizacija se javila $u$ situaciji B i $C$, ali ne i u situaciji A, dok se unutargrupna pristranost, mjerena Tajfelovim matricama, pojavila u sve tri situacije. Čini se da sama kategorizacija u grupu nije dovoljna za pojavu infrahumanizacije, no već i vrlo slaba identifikacija s grupom dovodi do njezina manifestiranja.

Što je identifikacija pojedinca s grupom snažnija, to je veća vjerojatnost da će se infrahumanizacija pojaviti (Leyens i sur., 2007.). U većem broju studija ispitanici koji se snažno identificiraju s grupom bili su skloniji infrahumanizaciji od onih koji se slabo identificiraju (Paladino i sur., 2004.; Viki, 2004.; prema Leyens i sur., 2007.). U nekima od tih studija efekt se pokazao i na ispitanicima niske identifikacije s grupom.

U istraživanju Vikija i Calitrija (2008.) ispitivana je veza infrahumanizacije s nacionalizmom i patriotizmom. Iako su ta dva koncepta međusobno bliska, razlikuju se u vrlo važnom svojstvu: patriotizam sadrži isključivo elemente nacionalnoga ponosa, dok nacionalizam sadrži i aspekt nacionalne isključivosti i unutargrupne zatvorenosti. Vodeći se tim određenjima pojmova, istraživači su postavili dvije suprotstavljene hipoteze. Ako je točna hipoteza o infrahumanizaciji, očekuje se povezanost negiranja ljudskosti vanjske grupe s nacionalizmom, ali ne i patriotizmom. Međutim, moguće je da je zapravo riječ o tzv. suprahumanizaciji. Tada se očekuje povezanost negiranja ljudskosti vanjske grupe s patriotizmom, ali ne i s nacionalizmom. Rezultati studije pokazali su pozitivnu povezanost negiranja ljudskosti vanjske grupe s nacionalizmom, ali negativnu s patriotizmom, na temelju čega su istraživači zaključili da se međugrupno ponašanje može objasniti infrahumanizacijom, a ne suprahumanizacijom.

Povezanost unutargrupne zatvorenosti i sklonosti infrahumanizaciji dovodi do brojnih negativnih ishoda u situacijama kada postoji sukob među grupama. Pokazalo se da je infrahumanizacija prediktor neprihvaćanja kolektivne krivnje zbog nizozemske uključenosti u genocid u Srebrenici (Zebel i sur., 2008.) i prediktor nesklonosti prihvaćanja muslimanskih imigranata u Europi (Zimmermann i sur., 2008.). Castano i Giner-Sorolla (2006.) utvrdili su medijatorski efekt infrahumanizacije u odnosu unutargrupne vezanosti i prihvaćanja kolek- 
DRUŠ. ISTRAŽ. ZAGREB

BR. 4 (118)

STR. $923-948$

LÖW, A.: PREGLED... GOD. 21 (2012),

tivne krivnje te opravdanja postupaka vlastite grupe. U svojem su istraživanju dvjema grupama sudionika (Britancima i stanovnicima SAD-a) predstavili izmišljenu priču o nesreći tijekom njihova sukoba s vanjskim grupama u prošlosti, za koju je u jednoj situaciji krivac bila vanjska grupa, a u drugoj njihova vlastita grupa. Za vanjske grupe odabrali su australske starosjedioce (za Britance), odnosno Indijance (za stanovnike SAD-a). U obje situacije sudionici su infrahumanizirali svoje bivše "neprijatelje" samo onda kada je povijest prezentirana tako da je njihova vlastita grupa bila odgovorna za nesreću. Kada priča o nesreći nije zahtijevala prihvaćanje kolektivne krivnje, infrahumanizacija se nije pojavila.

Slično istraživanje provedeno je i u kontekstu sukoba na prostorima bivše Jugoslavije. Čehajić i sur. (2009.) proveli su u Bosni i Hercegovini studiju u kojoj su srednjoškolce srpske etničke pripadnosti tražili da odgovore na niz pitanja o poslijeratnoj situaciji i o drugim etničkim skupinama. Prije odgovaranja na pitanja, polovicu sudionika podsjetilo se na odgovornost njihove grupe za ratne događaje tako što su trebali pročitati prikaz intervjua u kojem dvoje mladih ljudi razgovara o tome kako se nose sa zlodjelima vlastite grupe. Sudionici koje se podsjetilo na odgovornost njihove grupe iskazali su da vanjska grupa (Bošnjaci) osjeća manje sekundarnih emocija u odnosu na sudionike koje se nije podsjetilo na kolektivnu odgovornost. Tam i sur. (2007.) proveli su istraživački program kojim su htjeli ispitati kako se mogu poboljšati odnosi između katolika i protestanata u Sjevernoj Irskoj. Utvrdili su da infrahumanizacija predviđa nizak stupanj međugrupnog oprosta, što je osobita zapreka pomirenju, kada se uzmu u obzir nalazi mnogih istraživanja, prema kojima je upravo oprost ključan faktor koji vodi rješavanju sukoba i psihološkom oporavku zajednice (Myers i sur., 2009.).

\section{KRITIKE I PRIGOVORI KONCEPTUALIZACIJI}

Kritičari hipoteze o infrahumanizaciji tvrde da nesklonost pripisivanja sekundarnih emocija pripadnicima vanjske grupe ne mora nužno proizlaziti iz motivacije da vanjskoj grupi negiramo ljudskost, nego iz činjenice da pripadnike vanjske grupe jednostavno slabije poznajemo (Beaupré i Hess, 2003.). Naime, sekundarne su emocije, u usporedbi s primarnima, teže prepoznatljive u socijalnoj interakciji te nema univerzalnih načina njihova iskazivanja (Ekman, 1992.). Prema tome, sekundarne emocije možemo prepoznati kod drugih ljudi samo ako te ljude dobro poznajemo i ako smo s njima češće u interakciji. Manjak informacija za članove vanjske grupe može pojedinca dovesti do pogrešnoga zaključka da oni ne doživljavaju sekundarne emocije. Ako je točna hipoteza o poznatosti, 
DRUŠ. ISTRAŽ. ZAGREB GOD. 21 (2012),

BR. 4 (118),

STR. 923-948

LÖW, A.: PREGLED... javiti kada ljudi dobiju dovoljno informacija o članu vanjske grupe. Međutim, ako bi se efekt ipak javio, to bi išlo u prilog hipotezi o infrahumanizaciji. Kako bi provjerili koja je od suprotstavljenih pretpostavki točna, Cortes i sur. (2005.) proveli su istraživanje u kojem su varirali stupanj poznatosti ciljne osobe ispitaniku. Usporedili su broj sekundarnih emocija odabranih za sebe i za vlastitu grupu te za vanjske grupe različite (visoke i niske) poznatosti ispitaniku. Pokazalo se da nema razlike u broju odabranih sekundarnih emocija za različito poznate pripadnike vanjske grupe - efekt se javio neovisno o tome koliko im je osoba koju su procjenjivali bila poznata. Ovaj nalaz znači snažan dokaz za opovrgavanje glavne kritike Modela infrahumanizacije i pokazuje nam da isključivo kognitivno objašnjenje infrahumanizacije nema čvrste temelje.

\section{INFRAHUMANIZACIJA I OBLIKOVANJE SLIKE NEPRIJATELJA U MEDIJIMA}

Infrahumanizacija je, uz dehumanizaciju, jedan od najčešćih načina oblikovanja slike neprijatelja u medijima. Neprijatelj se u međugrupnim sukobima često prikazuje tako da se infrahumanizira, odnosno da mu se negiraju ljudske karakteristike te mu se pripisuju obilježja suphumanih bića (životinja). Stoga brojne primjere takvih opisa vanjskih grupa nalazimo $\mathrm{u}$ ratnoj propagandi.

Primjerice, u nacističkoj su propagandi Židovi poistovjećivani sa životinjama: polipima ("rasprostranjeni" posvuda), hijenama (zli i opasni) i ušima (naporni i dosadni) (Andrighetto, 2009.). Amerikanci su, pak, Indijance nazivali vukovima, da ih prikažu kao predatorske životinje (Drinnon, 1990.; prema Andrighetto, 2009.). Prilikom genocida u Ruandi 1994. godine, Hutui su opisivali Tutsije kao žohare. Jedan od pripadnika Interhamwea, ekstremist Hutu, ovako govori o svojem iskustvu prilikom genocida: "Kada smo slijedili Tutsije do močvare, više nismo vidjeli u njima ljudska bića. Bića poput nas, s istim mislima, osjećajima ... Lovili smo ih poput zvijeri - mi smo bili zvijeri, a oni su bili naš plijen ..." (Hatzfeld, 2004., 55; prema Andrighetto, 2009.).

Rezultati nekoliko istraživanja Goffa i sur. (2008.) sugeriraju da neprijateljska propaganda može utjecati na pojačavanje fenomena infrahumanizacije. Primjerice, $u$ analizi novinskih članaka o zločincima osuđenima na smrt, učestalost upotrebe riječi vezanih uz životinje bila je mnogo češća u člancima o crncima nego o bijelcima. No je li takav način prikaza informacija u medijima zaista opasan? Da bi se odgovorilo na to pitanje, proveden je eksperiment $\mathrm{u}$ kojem su ispitanici priređivani slikama majmuna i velikih mačaka. Nakon priređivanja, gledali su film u kojem policajac hvata i tuče bjegunca 
DRUŠ. ISTRAŽ. ZAGREB GOD. 21 (2012)

BR. 4 (118)

STR. $923-948$

LÖW, A.: PREGLED... bijelca ili crnca. Kada su priređeni slikom majmuna, bili su skloniji reći da je crnac zaslužio da ga policajac pretuče nego bijelac. Kada su bili priređeni slikom velike mačke, nisu se javile razlike između situacije $\mathrm{u}$ kojoj je akter bio crnac i situacije u kojoj je akter bio bijelac.

$\mathrm{Na}$ kraju valja dodati da, osim što mediji mogu poticati infrahumanizaciju, često i ljudi sami selektivno procesiraju informacije iz medija i interpretiraju ih tako da negiraju ljudskost pripadnicima vanjskih grupa. Takvu pristranost u procesiranju informacija iz medija pokazali su Cortes i sur. (2006.; prema Leyens i sur., 2007.) $\mathrm{u}$ istraživanju $\mathrm{u}$ kojem su ispitivali dosjećanje primarnih i sekundarnih emocija nakon čitanja novinskih vijesti o pripadnicima vlastite grupe i vanjske grupe.

\section{SMANJIVANJE INFRAHUMANIZACIJE}

Dosadašnja istraživanja nisu se mnogo bavila pokušajima reduciranja infrahumanizacije. U nekoliko studija provjeravano je hoće li doći do "rehumanizacije" ako pripadnici vanjske grupe izraze doživljavanje sekundarnih emocija, no to je izazvalo upravo suprotnu reakciju sudionika (Vaes i sur., 2003.). Jedan od alternativnih načina postizanja "rehumanizacije" mogao bi biti predstavljanje pripadnika vanjske grupe kao činitelja prosocijalnoga ponašanja. Drugim riječima, možda bi bilo učinkovito kada se njihova ljudska priroda ne bi prikazala pridavanjem atributa koji povećavaju ljudskost (sekundarnih emocija), nego opisom njihova konkretnog ponašanja koje upućuje na jedinstvene ljudske karakteristike, poput činjenja prosocijalnih ponašanja.

U ranijim istraživanjima "rehumanizacija" se pokušala postići i izazivanjem osjećaja empatije prema pripadnicima vanjske grupe opisima situacija u kojoj se nalaze, ali takvo što se nije pokazalo uspješnim (Cuddy i sur., 2007.). Moguće je da zadani podražaji nisu bili dovoljno jaki da se kod ispitanika izazove empatija, jer su prezentirane informacije o situaciji u kojoj se nalaze pripadnici vanjske grupe bile vrlo kratke i slabo informativne. U budućim studijama treba porazmisliti o poboljšanjima takvih nacrta.

Druge potencijalne strategije smanjenja infrahumanizacije možemo izvesti iz postojećih, dobro poznatih, teorijskih modela smanjenja međugrupnih nesnošljivosti, a koji se temelje na hipotezi kontakta. Takve metode zasnivale bi se na dekategorizaciji, odnosno personaliziranju kontakata između vlastite grupe i vanjske grupe (Brewer i Miller, 1984.) ili rekategorizaciji (Gaertner i Dovidio, 2000.), odnosno uvođenju nove nadređene kategorije koja bi obuhvaćala i vlastitu grupu i vanjsku grupu. Da bi potonja strategija mogla biti učinkovita, pokazuje istraživanje R. Gaunt (2009.) na Židovima i Arapima u Izraelu. Sudionici su trebali procijeniti u kojoj mjeri smatra- 
DRUŠ. ISTRAŽ. ZAGREB GOD. 21 (2012),

BR. 4 (118),

STR. 923-948

LÖW, A.: PREGLED...

\section{ZAKLJUČAK}

ju vlastitu grupu i vanjsku grupu dijelom Izraela. Što je percepcija pripadnosti vanjske grupe i vlastite grupe zajedničkoj nadređenoj kategoriji (Izrael) bila izraženija, to je bila manje izražena infrahumanizacija vanjske grupe.

Kako je izravan kontakt s pripadnicima vanjskih grupa ponekad teško postići u praksi, on se može ostvariti proširenim kontaktom (Wright i sur., 1997.), zamišljenim kontaktom (Crisp i Turner, 2009.) ili parasocijalnim kontaktom (Schiappa i sur., 2005.). Potonji je vrlo praktičan i mogao bi biti primjenjiv u kontekstu infrahumanizacije, jer se može provoditi preko medija, i to tako da se kroz medijsku sliku ili posebne oblike medijske propagande prikažu skladni odnosi koje pripadnici vlastite grupe imaju s pripadnicima vanjske grupe. Pri tome moramo imati na umu da je u prvom redu kvaliteta kontakta, a ne njegova kvantiteta, ključna za smanjenje infrahumanizacije (Brown i sur., 2007.).

Djelotvorna strategija mogla bi biti i poticanje vrijednosti jednakosti (engl. egalitarian values) kod pojedinaca (Leyens i sur., 2007.), što sugerira studija Pereira i sur. (2009.), u kojoj je utvrđeno da priređivanje sudionika takvim vrijednostima smanjuje percepciju prijetnje vanjske grupe i poboljšava stavove prema pripadnicima vanjske grupe. Povezano s time, smanjenje infrahumanizacije možda bi se moglo postići i osvještavanjem ljudi da čine infrahumanizaciju, odnosno da iskazuju jedan oblik predrasuda. Naime, utvrđeno je da bojazan ostavljanja dojma osobe koja ima predrasude i čini diskriminaciju može dovesti do kontroliranja automatskih procesa obradbe stereotipa i predrasuda, primjerice motivirati na egalitarno ponašanje pri interakciji s pripadnicima etničkih manjina (Dunton i Fazio, 1997.). Nadalje, osvještavanje predrasuda i isticanje socijalnih normi protiv njihova izražavanja može dovesti i do internalizacije tih normi (npr. Etzioni, 2000.). To onda dovodi do intrinzične motivacije za kontroliranje predrasuda, jer osoba njihovim iskazivanjem narušava vlastitu sliku o sebi kao osobi koja nema predrasude (Plant i Devine, 1998.).

Za učinkovito smanjenje infrahumanizacije vjerojatno bi najbolja bila kombinacija ovih strategija. No sve ove pretpostavke valja provjeriti u budućim istraživanjima.

Istraživanja sustavno potvrđuju Leyensov model infrahumanizacije. Isti rezultati dobiveni su za različite vanjske grupe, na eksplicitnim i implicitnim mjerama, uz primjenu različitih istraživačkih paradigmi. Riječ je o vrlo snažnom i opasnom međugrupnom fenomenu koji može imati dramatične posljedice za živote ljudi. Proces pripisivanja emocija drugima ne aktivira uobičajene sheme jednakosti i pravednosti, pa ni- 
DRUŠ. ISTRAŽ. ZAGREB GOD. 21 (2012), BR. $4(118)$

STR. $923-948$

LÖW, A.: PREGLED...

\section{BILJEŠKE}

smo svjesni da, kada grupe razlikujemo po njihovu doživljavanju emocija, zapravo provodimo snažnu diskriminaciju.

Iako se $\mathrm{u}$ prošlosti raspravljalo o uzroku infrahumanizacije, danas je jasno da je ona prije svega posljedica motivacijskih čimbenika. Štoviše, istraživanja na minimalnim grupama pokazuju da je, u kontekstu ostalih fenomena koji se javljaju u međugrupnim odnosima, infrahumanizacija jedan od rijetkih primjera koji se može gotovo potpuno objasniti motiviranim ponašanjem i rezoniranjem.

Zaključke o infrahumanizaciji moramo donositi vrlo oprezno, jer su gotovo sva istraživanja provedena isključivo na studentima. Iako rezultati pokazuju snagu fenomena, ne omogućuju generalizaciju glavnih zaključaka na čitavu populaciju. Valja replicirati eksperimente na različitim grupama $u$ populaciji, pa će se tek tada moći procijeniti kako se fenomen manifestira kod prosječnoga čovjeka.

Dosadašnje studije nisu se puno bavile pokušajima reduciranja infrahumanizacije, pa bi se u budućim istraživanjima valjalo posvetiti i pronalasku učinkovitih strategija za smanjivanje infrahumanizacije.

1 Ovdje se izraz "out-group" prevodi kao "vanjska grupa", što je najčešći termin u hrvatskim prijevodima sveučilišnih udžbenika s područja socijalne psihologije (npr. Aronson i sur., 2005.; Hewstone i Stroebe, 2002.) te literaturi hrvatskih autora vezanoj uz međugrupne sukobe (npr. Ajduković, 2003.). Termin "vanjska grupa" definira se kao grupa s kojom se pojedinac ne identificira (Aronson i sur., 2005.), za razliku od termina "vlastita grupa" ("in-group"), koji se odnosi na grupu s kojom se pojedinac identificira. Drugim riječima, vanjska je grupa za pojedinca "druga" grupa, grupa koja nije njegova.

2 Sentimenti su osjećaji usmjereni prema nekomu ili nečemu; McDougall ih definira kao "organizirani sustav emocionalnih dispozicija usmjerenih na ideju o nekom objektu" (1908.; prema Rimac, 1999.).

3 Ovdje se misli na emocije u širem smislu, kao pojam koji obuhvaća sve oblike emocionalnoga doživljavanja, pa će se u tom smislu rabiti i u daljnjem tekstu.

${ }^{4}$ IAT mjeri snagu automatskih asocijacija među pojmovima u pamćenju (Greenwald i sur., 1998.). Zadatak je sudionika što brže, pritiskom tipke, klasificirati pojmove iz četiri kategorije - dvije kategorije čine različiti koncepti, a dvije atributi različite valencije. Sudionicima se podražaji zadaju u dva bloka - u prvom se iste tipke rabe za klasificiranje koncepata i atributa koji su sukladni (npr. pripadnici bijele rase i pozitivno te pripadnici crne rase i negativno), dok se $u$ drugom iste tipke rabe za klasificiranje koncepata i atributa koji nisu sukladni (npr. pripadnici crne rase i pozitivno te pripadnici bijele rase i negativno). Pretpostavka je da se podražaji klasificiraju brže ako su sukladni (nego ako nisu), jer je snaga asocijacije među njima veća. Rezultat na testu jest razlika u vremenu latencije između dva bloka podražaja. 
DRUŠ. ISTRAŽ. ZAGREB GOD. 21 (2012),

BR. 4 (118),

LÖW, A.: PREGLED...
STR. 923-948

5 Prema modelu infrahumanizacije, infrahumanizacija se očituje prije svega u diferencijalnom pripisivanju doživljavanja emocija, a ne i drugih podražaja, pa bi se možda na ovom mjestu moglo prigovoriti da je izraz "infrahumanizacija" neprikladan te da se treba zamijeniti nekim drugim izrazom (npr. dehumanizacija). Međutim, Leyens i sur. (2007.) navode da se pri provjerama modela infrahumanizacije $u$ zadnje vrijeme rabe i drugi podražaji, poput riječi vezanih uz ljude i životinje. Svi takvi podražaji temelje se na istom principu, a taj je da označuju (ili asociraju) na nešto što je "jedinstveno ljudsko", odnosno nešto što "nije jedinstveno ljudsko", pa se mogu na jednak način kao i primarne i sekundarne emocije upotrijebiti za provjeru modela infrahumanizacije.

\section{LITERATURA}

Ajduković, D. (2003). Socijalna rekonstrukcija zajednice. U D. Ajduković (Ur.), Socijalna rekonstrukcija zajednice: psihološki procesi, rješavanje sukoba i socijalna akcija (str. 11-39). Zagreb: Društvo za psihološku pomoć.

Andrighetto, L. (2009). Ingroup's status and implicit attributions of humanity. Unpublished doctoral dissertation, University of Padova, Italy. Posjećeno 30. 1. 2009. na: http://paduaresearch.cab.unipd.it

Aronson, E., Wilson, T. D. i Akert, R. M. (2005). Socijalna psihologija. Zagreb: Mate.

Bandura, A. (1999). Moral disengagement in the perpetration of inhumanities. Personality and Social Psychology Review, 3(3), 193-209. doi:10.1207/s15327957pspr0303_3

Bandura, A. (2002). Selective moral disengagement in the exercise of moral agency. Journal of Moral Education, 31(2), 101-119. doi:10.1080/ 0305724022014322

Bandura, A., Underwood, B. i Fromson, M. E. (1975). Disinhibition of aggression trough diffusion of responsibility and dehumanization of victims. Journal of Research in Personality, 9(4), 253-269. doi:10.1016/ 0092-6566(75)90001-X

Bar-Tal, D. (1989). Delegitimization: The extreme case of stereotyping and prejudice. U D. Bar-Tal, C. F. Graumann, A. W. Kruglanski i W. Stroebe (Ur.), Stereotyping and prejudice: Changing conceptions (str. 169182). New York: Springer-Verlag.

Bar-Tal, D. (2000). Shared beliefs in a society: Social psychological analysis. Thousand Oaks, CA: Sage Publications.

Beaupré, M. G. i Hess, U. (2003). In my mind, we all smile: A case of in-group favoritism. Journal of Experimental Social Psychology, 39(4), 371-377. doi:10.1016/S0022-1031(03)00012-X

Boccato, G., Capozza, D., Falvo, R. i Durante, F. (2008). The missing link: Ingroup, outgroup, and the human species. Social Cognition, 26(2), 224-234. doi:10.1521/soco.2008.26.2.224

Boccato, G., Cortes, B., Demoulin, S. i Leyens, J. Ph. (2007). The automaticity of infra-humanization. European Journal of Social Psychology, 37(5), 987-999. doi:10.1002/ejsp.412 
DRUŠ. ISTRAŽ. ZAGREB GOD. 21 (2012) BR. $4(118)$

STR. $923-948$

LÖW, A.: PREGLED...
Brewer, M. B. i Miller, N. (1984). Beyond the contact hypothesis: Theoretical perspectives on desegregation. U N. Miller i M. B. Brewer (Ur.), Groups in contact: The psychology of desegregation (str. 281-302). Orlando, FL: Academic Press.

Brown, R. J., Eller, A., Leeds, S. i Space, K. (2007). Intergroup contact and intergroup attitudes: A longitudinal study. European Journal of Social Psychology, 37(4), 692-703. doi:10.1002/ejsp.384

Castano, E. i Giner-Sorolla, R. (2006). Not quite human: Infrahumanization in response to collective responsibility for intergroup killing. Journal of Personality and Social Psychology, 90(5), 804-818. doi:10.1037/0022-3514.90.5.804

Cortes, B. P., Demoulin, S., Rodriguez, R. T., Rodriguez, A. P. i Leyens, J. Ph. (2005). Infrahumanization or familiarity? Attribution of uniquely human emotions to the self, the ingroup, and the outgroup. Personality and Social Psychology Bulletin, 31(2), 253-263. doi:10.1177/0146 167204271421

Crisp, R. J. i Turner, R. N. (2009). Can imagined interactions promote positive perceptions? Reducing prejudice through simulated social contact. American Psychologist, 64(4), 231-240. doi:10.1037/a0014718

Cuddy, A. J. C., Rock, M. S. i Norton, M. I. (2007). Aid in the aftermath of hurricane Katrina: Inferences of secondary emotions and intergroup helping. Group Processes and Intergroup Relations, 10(1), 107-118. doi:10.1177/1368430207071344

Čehajić, S., Brown, R. i Gonzalez, R. (2009). What do I care? Perceived ingroup responsibility and dehumanization as predictors of empathy felt for the victim group. Group Processes and Intergroup Relations, 12(6), 715-729. doi:10.1177/1368430209347727

Delgado, N., Rodriguez, A., Vaes, J., Leyens, J. Ph. i Betancourt, V. (2009). Priming effects of violence on infrahumanization. Group Processes and Intergroup Relations, 12(6), 699-714. doi:10.1177/136843020 9344607

Demoulin, S., Cortes, B. P. i Leyens, J. Ph. (2009). Infra-humanization: The differential interpretation of primary and secondary emotions. U S. Demoulin, J. Ph. Leyens i J. F. Dovidio (Ur.), Intergroup misunderstandings: Impact of divergent social realities (str. 153-172). New York: Psychology Press.

Demoulin, S., Leyens, J. Ph., Paladino, M. P., Rodriguez, R. T., Rodriguez, A. P. i Dovidio, J. F. (2004a). Dimensions of "uniquely" and "non-uniquely" emotions. Cognition and Emotion, 18(1), 71-96. doi:10. 1080/02699930244000444

Demoulin, S., Leyens, J. Ph., Rodriguez, R. T., Rodriguez, A. P., Paladino, M. P. i Fiske, S. T. (2005). Motivation to support a desired conclusion versus motivation to avoid an undesirable conclusion: The case of infra-humanization. International Journal of Psychology, 40(6), 416-428. doi:10.1080/00207590500184495

Demoulin, S., Rodriguez, R. T., Rodriguez, A. P., Vaes, J., Paladino, M. P., Gaunt, R., Cortes, B. P. i Leyens, J. Ph. (2004b). Emotional prejudice can lead to infra-humanization. U W. Stroebe i M. Hewstone (Ur.), European Review of Social Psychology (Vol. 15, str. 259-296). London: Psychology Press. 
DRUŠ. ISTRAŽ. ZAGREB GOD. 21 (2012), BR. 4 (118),

STR. 923-948

LÖW, A.: PREGLED...
Dunton, B. C. i Fazio, R. H. (1997). An individual difference measure of motivation to control prejudiced reactions. Personality and Social Psychology Bulletin, 23(3), 316-326. doi:10.1177/0146167297233009

Ekman, P. (1992). An argument for basic emotions. Cognition and Emotion, 6(3-4), 169-200. doi:10.1080/02699939208411068

Etzioni, A. (2000). Social norms: Internalization, persuasion, and history. Law \& Society Review, 34(1), 157-178. doi:10.2307/3115119

Fiske, S. T., Cuddy, A. J. C., Glick, P. i Xu, J. (2002). A model of stereotype content: Often mixed, competence and warmth respectively follow from perceived status and competition. Journal of Personality and Social Psychology, 82(6), 878-902. doi:10.1037//0022-3514.82.6.878

Gaertner, S. L. i Dovidio, J. F. (2000). Reducing intergroup bias: The common ingroup identity model. Philadelphia, PA: Psychology Press.

Gaunt, R. (2009). Superordinate categorization as a moderator of mutual infrahumanization. Group Processes and Intergroup Relations, 12(6), 731-746. doi:10.1177/1368430209343297

Gaunt, R., Leyens, J. Ph. i Demoulin, S. (2002). Intergroup relations and the attribution of emotions: Controllability of memory for secondary emotions associated to ingroup versus outgroup. Journal of Experimental Social Psychology, 38(5), 508-514. doi:10.1016/S0022-1031 (02)00014-8

Gaunt, R., Sindic, D. i Leyens, J. Ph. (2005). Intergroup relations in soccer finals: People's forecasts of the duration of emotional reactions of in-group and out-group soccer fans. Journal of Social Psychology, 145(2), 117-126. doi:10.3200/SOCP.145.2.117-126

Goff, P. A., Eberhardt, J. L., Williams, M. J. i Jackson, M. C. (2008). Not yet human: Implicit knowledge, historical dehumanization, and contemporary consequences. Journal of Personality and Social Psychology, 94(2), 292-306. doi:10.1037/0022-3514.94.2.292

Greenwald, A. G., McGhee, D. E. i Schwartz, J. L. K. (1998). Measuring individual differences in implicit cognition: The implicit association test. Journal of Personality and Social Psychology, 74(6), 1464-1480. doi:10.1037//0022-3514.74.6.1464

Haslam, N. (2006). Dehumanization: An integrative review. Personality and Social Psychology Review, 10(3), 252-264. doi:10.1207/s15327957 pspr1003_4

Haslam, N., Loughnan, S., Reynolds, C. i Wilson, S. (2007). Dehumanization: A new perspective. Social and Personality Psychology Compass, 1(1), 409-422. doi:10.1111/j.1751-9004.2007.00030.x

Hewstone, M. i Stroebe, W. (2002). Socijalna psihologija. Jastrebarsko: Naklada Slap.

Kofta, M., Miroslawska, M. i Blogowska, J. (2008). Ingroup bias and infrahumanization: Related or unrelated phenomena? Paper presented at the EAESP Small Group Meeting on Dehumanization: Determinants and Consequences of Perceiving Others as Less Than Humans, Kazimierz Dolny, Poland.

Leyens, J. Ph., Cortes, B. P., Demoulin, S., Dovidio, J., Fiske, S. T., Gaunt, R., Paladino, M. P., Rodriguez, A. P., Rodriguez, R. T. i Vaes, V. 
DRUŠ. ISTRAŽ. ZAGREB GOD. 21 (2012) BR. 4 (118),

STR. $923-948$

LÖW, A.: PREGLED...
(2003). Emotional prejudice, essentialism, and nationalism. European Journal of Social Psychology, 33(6), 703-717. doi:10.1002/ejsp.170

Leyens, J. Ph., Demoulin, S., Vaes, J., Gaunt, R. i Paladino, M. P. (2007). Infra-humanization: The wall of group differences. Journal of Social Issues and Policy Review, 1(1), 139-172. doi:10.1111/j.1751-2409. 2007.00006.x

Leyens, J. Ph., Paladino, P. M., Rodriguez, R. T., Vaes, J., Demoulin, S., Rodriguez, A. P. i Gaunt, R. (2000). The emotional side of prejudice: The attribution of secondary emotions to ingroups and outgroups. Personality and Social Psychology Review, 4(2), 186-197. doi:10.1207/ S15327957PSPR0402_06

Leyens, J. Ph., Rodriguez, A. P., Rodriguez, R. T., Gaunt, R., Paladino, P. M., Vaes, J. i Demoulin, S. (2001). Psychological essentialism and the differential attribution of uniquely human emotions to ingroups and outgroups. European Journal of Social Psychology, 31(4), 395-411. doi:10.1002/ejsp.50

Myers, E., Hewstone, M. i Cairns, E. (2009). Impact of conflict on mental health in Northern Ireland: The mediating role of intergroup forgiveness and collective guilt. Political Psychology, 30(2), 269-290. doi:10.1111/j.1467-9221.2008.00691.x

Opotow, S. (1990). Moral exclusion and injustice: An introduction. Journal of Social Issues, 46(1), 173-182. doi:10.1111/j.1540-4560.1990. tb00268.x

Opotow, S., Gerson, J. i Woodside, S. (2005.). From moral exclusion to moral inclusion: Theory for teaching peace. Theory Into Practice, 44(4), 303-318. doi:10.1207/s15430421tip4404_4

Paladino, P. M., Leyens, J. Ph., Rodriguez, R. T., Rodriguez, A. P., Gaunt, R. i Demoulin, S. (2002). Differential association of uniquely and non uniquely human emotions to the ingroup and the outgroups. Group Processes and Intergroup Relations, 5(2), 105-117. doi:10. $1177 / 13630202005002539$

Paladino, M. P., Vaes, J., Castano, E., Demoulin, S. i Leyens, J. Ph. (2004). Emotional infrahumanization in intergroup relations: The role of national identification in the attribution of secondary emotions to Italians and Germans. Current Psychology of Cognition, 22(4-5), 519-536.

Pereira, C., Vala, J. i Leyens, J. Ph. (2009). From Infra-humanization to discrimination: The mediation of symbolic threat needs egalitarian norms. Journal of Experimental Social Psychology, 45(2), 336-344. doi:10.1016/j.jesp.2008.10.010

Plant, E. A. i Devine, P. G. (1998). Internal and external motivation to respond without prejudice. Journal of Personality and Social Psychology, 75(3), 811-832. doi:10.1037//0022-3514.75.3.811

Rimac, I. (1999). Osnovne psihologijske odrednice formiranja političkih preferencija. Neobjavljena doktorska disertacija. Filozofski fakultet, Zagreb. Posjećeno 19. 7. 1999. na: https://bib.irb.hr

Rohmann, A., Niedenthal, P. M., Brauer, M., Castano, E. i Leyens, J. Ph. (2005). The attribution of primary and secondary emotions to the 
DRUŠ. ISTRAŽ. ZAGREB GOD. 21 (2012), BR. 4 (118),

STR. 923-948

LÖW, A.: PREGLED... in-group and to the out-group: The case of equal status countries. Journal of Social Psychology, 149(6), 709-730. doi:10.1080/002245409 03348253

Schiappa, E., Gregg, P. i Hewes, D. (2005). The parasocial contact hypothesis. Communication Monographs, 72(1), 92-115. doi:10.1080/03 63775052000342544

Schwartz, S. H. i Struch, N. (1989). Values, stereotypes, and intergroup antagonism. U D. Bar-Tal, C. F. Graumann, A. W. Kruglanski i W. Stroebe (Ur.), Stereotyping and prejudice: Changing conceptions (str. 151-167). New York: Springer-Verlag.

Staub, E. (1989). The roots of evil: The origin of genocide and other group violence. Cambridge: Cambridge University Press.

Tajfel, H. (1981). Human groups and social categories. Cambridge: Cambridge University Press.

Tajfel, H., Billig, M., Bundy, R. P. i Flament, C. (1971). Social categorization and intergroup behaviour. European Journal of Social Psychology, 1(2), 149-178. doi:10.1002/ejsp.2420010202

Tam, T., Hewstone, M., Cairns, E., Tausch, N., Maio, G. i Kenworthy, J. (2007). The impact of intergroup emotions on forgiveness in Northern Ireland. Group Processes and Intergroup Relations, 10(1), 119-136. doi:10.1177/1368430207071345

Vaes, J. i Paladino, M. P. (2008). The uniquely human content of stereotypes. Paper presented at the EAESP Small Group Meeting on Dehumanization: Determinants and Consequences of Perceiving Others as Less Than Humans, Kazimierz Dolny, Poland.

Vaes, J., Paladino, M. P., Castelli, L., Leyens, J. Ph. i Giovanazzi, A. (2003). On the behavioral consequences of infra-humanization: The implicit role of uniquely human emotions in intergroup relations. Journal of Personality and Social Psychology, 85(6), 1016-1034. doi:10.1037/ 0022-3514.85.6.1016

Vaes, J., Paladino, M. P. i Leyens, J. Ph. (2006). Priming uniquely human emotions and the in-group (but not the out-group) activates humanity concepts. European Journal of Social Psychology, 36(2), 169-181. doi:10.1002/ejsp.279

Viki, G. T. i Calitri, F. (2008). Infrahuman outgroup or suprahuman ingroup: The role of nationalism and patriotism in the infrahumanization of outgroups. European Journal of Social Psychology, 38(6), 1054 1061. doi:10.1002/ejsp.495

Viki, G. T., Winchester, L., Titshall, L., Chisango, T., Pina, A. i Russell, R. (2006). Beyond secondary emotions: The infrahumanization of out-groups using human-related and animal-related words. Social Cognition, 24(6), 753-775. doi:10.1521/soco.2006.24.6.753

Wright, S. C., Aron, A., McLaughlin-Volpe, T. i Ropp, S. A. (1997). The extended contact effect: Knowledge of cross-group friendships and prejudice. Journal of Personality and Social Psychology, 73(1), 73-90. doi:10. 1037//0022-3514.73.1.73

Zebel, S., Zimmermann, A., Viki, G. T. i Doosje, B. (2008). Dehumanization and guilt as distinct but related predictors of support for repa- 
DRUŠ. ISTRAŽ. ZAGREB GOD. 21 (2012),

BR. $4(118)$

STR. $923-948$

LÖW, A.: PREGLED... ration policies. Political Psychology, 29(2), 193-219. doi:10.1111/j.14679221.2008.00623.x

Zimmermann, A., Doosje, B., Zebel, S., Viki, G. T. i Abrams, D. (2008). Dehumanization and moral responsibility as predictors of outgroupfocused outcomes and support for terror threat prevention. U J. Martin Ramirez, T. K. Walters i M. Kossowska (Ur.), 2008 CICA-STR International Conference on Aggression, Terrorism and Human Rights: Program and Abstracts (str. 58). http://eprints.ucm.es/11808/1/CICASTR_ booklet_17_06_08.pdf

\section{Research on the Infrahumanization Effect: A Review}

Ajana LÖW

Faculty of Humanities and Social Sciences, Zagreb

Infrahumanization refers to the tendency to deny human characteristics to members of the out-group, which is reflected in a lower attribution of experiencing secondary emotions to the out-group than to the in-group (Leyens et al., 2000). This differential attribution is a consequence of the assumption that humans have the exclusive possibility of experiencing secondary emotions: while experiencing primary emotions is universal to both humans and animals, experiencing secondary emotions is a process unique to humans. Studies in the area have systematically confirmed the existence of the infrahumanization effect, using explicit and implicit measures, along with different stimulus materials. The best predictor of occurrence of the effect is the degree of in-group identification, while relative group status and prior conflict between groups are less important than it has been assumed. Infrahumanization is difficult to reduce because it is the result of automatic cognitive processes, and the environment encourages its intensification and maintenance. In this paper, the current knowledge on infrahumanization is reviewed and the most common methods used to assess this phenomenon are described. Moreover, the conditions that lead to infrahumanization, in terms of the in-group and out-group characteristics, are presented. In addition, the critics of the conceptualization are described. Finally, some social implications of this phenomenon are presented, along with the guidelines for future research.

Keywords: infrahumanization, denial of humanity, intergroup relations, emotion experience attributions 